\title{
Learning to Stay Ahead of Time Moving Leadership Experiences Experimentally
}

\author{
Raffnsøe, Sverre; Staunæs, Dorthe
}

Document Version

Accepted author manuscript

Published in:

Management \& Organizational History

DOI:

10.1080/17449359.2014.891794

Publication date:

2014

\section{License}

Unspecified

Citation for published version (APA):

Raffnsøe, S., \& Staunæs, D. (2014). Learning to Stay Ahead of Time: Moving Leadership Experiences Experimentally. Management \& Organizational History, 9(2), 184-201.

https://doi.org/10.1080/17449359.2014.891794

Link to publication in CBS Research Portal

\section{General rights}

Copyright and moral rights for the publications made accessible in the public portal are retained by the authors and/or other copyright owners and it is a condition of accessing publications that users recognise and abide by the legal requirements associated with these rights.

Take down policy

If you believe that this document breaches copyright please contact us (research.lib@cbs.dk) providing details, and we will remove access to the work immediately and investigate your claim. 


\section{Learning to Stay Ahead of Time: Moving Leadership Experiences Experimentally}

\section{Sverre Rafnnsøe and Dorthe Staunæs}

Journal article (Post print version)

This is an Accepted Manuscript of an article published by Taylor \& Francis in Management \& Organizational History on 03 Mar 2014, available online:

http://www.tandfonline.com/10.1080/17449359.2014.891794.

Uploaded to Research@CBS: June २०16 


\section{Learning to stay ahead of time.}

\section{Moving leadership experiences experimentally}

Authors: Sverre Raffnsøe and Dorthe Staunæs

Institutions: Copenhagen Business Schoolsra.mpp@cbs.dk, Aarhus Universitydost@dpu.dk

You will learn what all of our pilgrim companions have learned on the Santiago Road: the going is more memorable than the getting there. David M. Gitlitz and Linda Kay Davidson: The Pilgrimage Road to Santiago, $X I$

Experiences and assertions of living through processes and transformations that radically re-arrange the world and society in which we live abound (Drucker 1993; Harvard business review's 10 must reads on change 2011). In economics, organizational studies and management theory, moreover, radical and all-encompassing change is no longer regarded as an isolated or transitional state of exception but as an on-going condition and challenge (Drucker 2008; Hamel and Prahalad 1996).

The future is already here as a movement that is outdoing and changing the past and the present.

In turn, the arrival of the future in the form of an on-going transformation of the past and the present raises a pressing concern in organizational and economic life: how to respond, at least adequately and preferably more than adequately, to this challenge. The ability to stay ahead of the time arriving by persistently responding and reproducing new time has become imperative (Hamel 2007; Drucker 2007; Senge 1990; Schumpeter 1947; Florida 2002). Building a capacity for getting and staying ahead of time in a process of on-going response and renewal is experienced as a do-or-die challenge for any company, organization and society that hopes to survive and thrive in the chequered times ahead (Nelson and Winter 1982; Prahalad and Hamel 1990; Teece et al. 1997; Boisot 1999). 
Currently, management is viewed as the crux of the endeavour to develop an organisational culture and response on par with and ahead of these challenges. Management as "the capacity to marshal resources, lay out plans, program work, and spur effort" (Hamel 2007, X) is seen as decisive for an organization's or a nation's ability to stay ahead of time.

Within this setting, managing and initiating change is not concerned with altering or modifying an organization that would otherwise have been stable and unchanging. Change management is concerned with leading in a culture of change (Fullan 2001). Change is always already on its way, as management seeks to ally itself with it, respond to it, redirect it and, at its very best, anticipate and stay ahead of it

For some time, it has been a common adage that, to the extent management wishes to stay ahead of time; it cannot content itself with administering and coordinating the activities of the organisation to accomplish certain desired goals. It must essentially take the form of leadership, forging ahead and clearing a path into the future. Yet, this article argues that, in the context of an on-going intervening change, management can no longer simply stay ahead and blaze a trail for others to follow by assuming the traditional form of leadership, pointing out certain fixed common goals that one should achieve or, at least, move towards. Management is required to move ahead of and beat time, as it takes the form of a leadership that must be re-ignited over and over again. Practicing and experimenting with the capacity to stay ahead of time becomes a core activity of and an essential prerequisite for leadership.

Today, many resources are spent on upgrading management and managerial capacity for leadership. Over the last 15-20 years, there has been a great interest in generating practitioners who are able to reflect (Schön 1983) and who are able to implement thoroughly considered (Ratner. 2012) and emotional leadership (Howe 2008; Goleman 1996; Sinclair and Wilson 2002; Blackmore 2011). 
This interest may be traced in the establishment of leadership programmes, modules and courses that take the shape of "management learning" (Elkjær and Vince 2009; Sinclair 1998; Sinclair and Wilson 2002). Management learning marks a shift from the education of managers to the development of managers as leaders.

To create leaders from whom the organisation may benefit, organisations are beginning to create specific learning laboratories for leaders. When the drivers of organisational change - the leaders take part in the laboratory, they partake in an organised, realistic, but also experimental practice in temporary seclusion from daily organisation, so as subsequently to enter into the daily organisation in a more qualified manner - thereby contributing to general organisational productivity.

Especially the advent of the leadership learning laboratories (LLL) marks a shift from training and instruction to an on-going formation of improvement for leadership and managers as leaders. This article investigates what occurs when organisational management begins to take part in such a setting. The lab is not a site created for instruction in or acquisition of a particular kind of knowledge, specific qualifications, or specialized competencies. Instead, the leadership learning laboratory is a setting in which the primary object is the appropriation of a certain habitus. In the lab, it is essential that the leader appropriates a readiness to act: a capacity to anticipate by turning into a responsive relationship with what he or she encounters.

The article examines the kind of leadership but also the attitudes towards the future that appear when managers partake in the laboratory settings to enhance their capacity for leadership. The article shows how the laboratory becomes a site for learning, which brings affect into play as its primary medium to achieve a certain effect of its own make, viz., the development of a certain innate humanity as it appears in a capacity to relate to and respond to other human beings. When managers enter the lab, it becomes possible to conjure up, revitalize and intensify a particularly 
human attitude in and toward human relations. This attitude involves acquiring a capacity for being oriented towards the future and responding to the effects of what is not necessarily in continuation with the present but on its way and coming into being, so that he or she is ahead of time.

The article analyses a specific and, perhaps, rather spectacular leadership learning laboratory: a corporate pilgrimage leadership learning lab (PLLL). This lab was designed as a six-day corporate journey along the traditional pilgrimage route, El Camino, leading to Santiago del Compostela in northern Spain. The lab was an in-house-design, invented and created by a major, transnational corporation - more particularly, by their in-house philosopher. Participants included CEOs, the philosopher, HR and PR employees from the corporation but also a Special Forces soldier, a TV crew and, not least, four previously convicted men from an ethnic and religious minority. The corporation offered the prospect of trainee positions in the company to the four men if they participated actively in the journey. As the CEO put it: "I want to get four grown-up, Muslim, mature, well-considered and successful men out of this. That's what I want!' By casting the young men as the organizational Others (Czarniawska-Joerges and Höpfl 2002), the pilgrimage lab could demonstrate social responsibility. In this article, however, we focus on leadership learning and only touch sporadically on the subject on corporate social responsibility and on the learning processes of the young men.

From the perspective of leadership learning, the corporate pilgrimage calls attention to general features of the learning lab in a cleansed and heightened form, as the (PLLL) emphasises how the learning lab involves an on-going journey towards a future goal that has not yet been and may never be reached. Instead, a matter of vital importance is the development of a capacity to respond as a human being to unforeseeable challenges along the road, to the eventual in an incomplete future. 


\section{A diffractive methodology}

Empirical, historical and conceptual in character, this article elucidates the characteristics of the actual LLL through juxtaposition with previous related arrangements that facilitate leadership learning. Thus, the article may also be regarded as an attempt to write history and a diagnosis of contemporary experiences into management and leadership research (MoH 2013, 105-196).

This juxtaposition permits a diffractive analysis or reading of the PLLL. Diffraction refers to the phenomenon that occurs when waves pass through one medium to another with a different refractive index. Studying the way in which the waves are refracted, the way they continue and change as they pass on, provides insight into the characteristics of and relationship between the media and locii that the various kinds of waves traverse, whether they are light waves, electromagnetic waves or sound waves (Haraway 1992).

Employing a diffractive approach or methodology, thus, makes it possible to put together, contrast and compare various related arrangements with a particular attention to the patterns of difference and displacements in view (Barad 2007) . By performing a diffractive reading of the PLLL, the article seeks to articulate the characteristics of this particular lab. However, the article does so precisely by examining the various diffractions that occur as one passes from previous sites and enter into the lab. In its pluri-dimensional relationship to other arrangements, the PLLL appears in its peculiarity as a displacement of the previously given.

\section{Leadership learning laboratories}

The article engages in a diffractive analysis of the PLLL, as it places this peculiar lab side by side with three other arrangements. The characteristics of the LLL and the basic features of its futureoriented attitude (becoming ever-more common in modern management settings) are developed, refracted and mirrored as the LLL is contrasted with an analogous and related but differentlyoriented longstanding historical tradition for leadership learning, ranging from antiquity to late 
modernity, that have been trendsetting in Western society. The first is the tradition of counsel for princes, articulated in the important advice literature directed toward rulers, known as mirrors of princes (principum speculae, Fürstenspiegel). This tradition is closely connected to the traditional concept of leadership as it is exercised as a form of rule over a certain field or territory. In addition, the PLLL is compared to and refracted with newer and upcoming leadership learning courses involving animals: the rabbit killer courses from the 1980s and equine-assisted coaching from the 2000s.

These arrangements are all connected to, mirror and refract the PLLL insofar as they can be viewed and analysed as leadership laboratories. They are all laboratories insofar as they form a particular enclosure in which it is possible to create a controlled setup that makes it possible to work (laborare) particularly actively and intensively on experimenting and creating experiences (Latour 1988; Latour and Woolgar 1986; Livingstone 2003)

In general, the laboratory is characterised by a cleansing and control of a given designed space. Within this controlled setting, irrelevant and disturbing influences can be removed and otherwise existing power configurations may be consciously manipulated and reversed (Latour 1988). In this way, it is possible to organise a continued experimentation, combined with an on-going observation of its consequences, in order to make discoveries and establish knowledge concerning the field at hand (Latour 1988). In the case of the LLL, a controlled setting is created in which it is possible to work actively on experimenting and creating experiences in the field of leadership learning.

As already suggested, however, the lab is not to be understood as a passive means to cognition but as an "apparatus" (Barad 2007) that permits its participants to come to a knowledge of truth precisely because it is "a complex game of construction and mobilization" (Brown 2012) that actively affects conduct and modulates the learning and the attitude of the field investigated. The 
LLL are to be understood and analysed as "dispositives" that exert a determining influence on and actively affect the dispositions of their participants in various ways, not only within the specific setting established but also within a wider context (Raffnsøe et al. 2014; Foucault 1980; Raffnsøe 2002a). In general, the learning apparatuses at hand are articulated and analysed. Still, they are not explored thoroughly in their own right but primarily studied to set off the specificities and effects of the PLLL more clearly, including the basic features of its future-oriented attitude. By using this methodology in analysing this somewhat spectacular leadership learning activity, the article aims at contributing to a more general discussion of contemporary leadership learning.

\section{An ontology of not-yet-being}

On the basis of the established historical contrast, the article conceptualizes general characteristics of the pilgrimage leadership learning lab. In contrast with the mirror of princes, this lab is a moveable leadership learning laboratory that creates situations of extraordinary intensity that border on hyper-reality and force the leader to find herself anew on the verge of herself. As the leader is confronted with what is conceived as a cultural-religious-ethnic otherness, she is forced to lose control and transform herself. In opposition to the ideal of princely self-containment, an essential objective of this transformation is the acquisition of relational competences. In particular, this openness includes a potential for being affected in ways that permit to anticipate what is still in becoming. For leadership, an orientation towards the future, "anticipatory affects" (Bloch 1959) and the "virtual" (Massumi 2002; Deleuze and Guattari 1991) as a coming into being takes up a predominant role. While the mirror of princes aimed at developing the leader's humanity in general, the contemporary lab opens a space for a situated and particular humanity in an on-going transformation, heading towards the future. Conceived as pilgrimage, leadership moves ahead of time as it reaches into and anticipates a future still unknown. In this sense of being still in 
development, leadership distinguishes itself from traditional leadership, management and governmentality.

Generated in connection with the psy-management project (Staunæs et al. 2009), the empirical material consists of an interview with the managing director, a TV-program The Boss and the Lads, a radio program Human Beings and Belief, a book When Philosophy Takes Effect (Paustian 2012), written by the company's in-house philosopher and a number of Danish newspaper articles. The historical material is from the dissertation Sameksistens uden commonsense (Raffnsøe 2002abc). The material concerning rabbit-killer courses and equine management coaching has been produced through interviews with a coach, participant observation, and Internet searches.

\section{Leadership training and character formation}

The Western tradition of counselling princes may be conceived as an apparatus that forms an important precursor of the corporate pilgrimage. Even here, the purpose was to improve existing leadership. The tradition of counselling princes aimed at preparing leaders to assume leadership in the proper way for individuals in the context of their communities, from the private oikos to the larger household of the city-state or even large empires (Gray 2011). Usually, the counselling, formation and education of the leader in this protreptic tradition (Aristotle 1964) involved retreating from daily management as an essential part of the pedagogical aspect. Suspending everyday 'managerial' decision-making, the prince would retreat to his antechamber with an advisor. This was done not only to (re)consider the situation on a broader basis but also to permit the prince to scrutinize, work through and develop his own habitus in general in collaboration with his aide. In this way, the formation of the prince's attitude through counselling was intended to build character and pave the way for better deliberation, more pertinent decisions and leadership in the time to come. 
When retreating into the closed camera (chamber), the prince and his educative counsellor entered a controlled setting and formed an experimental laboratory in which the power balances could, at least to some extent be dislocated, and the characteristics of leadership could be examined, developed and learned.

The character of this tradition of counselling princes has been handed down to us in a literary genre of 'the mirror of princes', which can be traced back to antiquity and extends up to, at least, the beginning of the 1700s (Raffnsøe 2002c). Among the early works that can be associated with and viewed as a predecessor to this genre are Plato's Seventh Letter (Plato 2008), Xenophon's The Education of Cyrus (Xenophon 1960; Xenophon1953), and Seneca's De Clementia (Seneca 1979). An outstanding example among a number of subsequent and important representatives is Thomas Aquinas' De regimine principum (1266), written for the king of Cyprus, (Thomas 1948). These numerous documents are instructional, directed at a specific prince or emerging regent, and written for individual study. Thus, in acquiring a basis for proper regency, the prince was able to lead others and make the right decisions. These texts, therefore, concern the acquisition and heightening of leadership ability.

The genre of the mirror of princes provided an outline of the ideal reign in which the prince could mirror his deeds and government so that his governance could function as an ideal for the subjects of the realm to follow. The prince's own general character formation was thereby a core precondition for his ability to lead men.

Within this tradition, leadership is closely associated with rule and dominance. By entering into and attaining character formation through such basic and preparatory counsel, which gave the prince knowledge of the right measure and control of his own emotions, the prince was able to rise above his fellow human beings and exercise dominance and power over others (Raffnsøe 2014). By 
building a human character in a way that allows him to know the right way ahead and to stay in control of his feelings, the ruler was able to rise above his fellow human beings and assume the position of the helmsman and lead them. Assuming his natural position as a "helmsman" (Thomas 1948) over the crew, the ruler should be able to dominate them and ensure a steady course as he takes command, indicates the common destination and finds the right means to reach his goal, even when he has to negotiate adverse winds and cross dangerous seas. In the mirror of princes and the laboratory of protreptics, attention on character formation is an essential part of leadership training.

\section{A moveable setting}

Let us now examine the location and instruments of the PLLL and, as an extension thereof, scrutinise what this lab makes the participants capable of. From the previous remarks, we recall the laboratory as a particular, delimited location, which was arranged so that it became possible to work intensively with certain cleansing elements in order to have experiences of an exemplary character. Furthermore, we remember the location of the mirror of princes as a refuge, as a secluded and undisturbed location, to which the regent could withdraw in order to develop, contemplate, generate experience and improve his leadership.

As with the mirror of princes, PLLL is a particular refuge. However, unlike the mirror of princes, this lab is not a cleansed human space. Like the classical laboratory, the PLLL contains and activates the figure of the human in regard to a number of non-human actors. This lab mixes and amplifies selected features from as well the mirror of princes as the classical laboratory, so that a third type of setting appears. This requires an explanation.

The laboratory takes place in a picturesque but wild countryside. It is nature; and yet, the Camino is an ancient path taken by many others who have sought a spiritual goal through physical means by visiting small villages and ancient churches. Already here, we see how nature and culture cannot be separated but are entangled with, by and through each other. Nature creates culture, and culture 
creates nature (Haraway 1992). They are entanglements (Barad 2007). It is exactly this location, and the journey that can take place, that makes the PLLL at once an open and closed effort, an experience that is simultaneously calm and in flux. But as opposed to the asceticism in the mirror of princes and the calmness and sterility of a classical laboratory, imperfections, complexity and unpredictability are elements inherent in and vital to the LLL.

The pilgrimage challenges the classical definition of laboratory insofar as one conceives of it as a fixed, closed space inside a building, since the journey is characterised by a continuous movement across ever-changing topoi, even though the trajectory follows an already given route that has been traversed by thousands of people. Still, the PLLL constitutes seclusion from everyday organisational life and takes place in a completely different setting. As the participant's bodies constantly move through time and space, the event becomes a laboratory moving in time and space: a unified experimental event that is upheld as a context for the participant's shared actions and imagination.

Borrowing features from both of them, the PLLL does not simply take the place and supplant and erase the classical laboratory and the mirror of princes. As implied, it is also a complex, hybrid device. The PLLL exists in an extension of the two predecessors, which constitute decisive preconditions, even as they are brought together in a unique configuration. On the one hand, the lab becomes a locus where the precursory elements are united and refracted; on the other hand, traits from these precursors enter into and are refracted within the context of the lab. Similarities and differences occur. It is a prerequisite for the PLLL that the arrangements of the classical laboratory and counselling for princes have become fairly natural settings. In this case, the delimitation of the leadership laboratory can be transported and moved about between localities, even as it can draw upon and change varying contexts without having to seek support in a given, physical-material delimitation (Michael 1996) or topos (Livingstone 2003). 


\section{Intense relations and real life}

Leadership learning needs "real life" rather than scholastic life; it is noted by the CEO in the following quote. Real life is not identical with ordinary practices in the office. It is more like a kind of intensified life. Farther along in the quote, she notes the constitutive force of reality for what can be actualized:

I want to provide my managers with exceptional skills in building up relations where it is difficult to manage, so to speak, and against all odds. That means that, where the odds are different and the setting unfamiliar, your capacity, the part of yourself that you need to access and cultivate, is really something you should use very much in your everyday life. You can't train these features. In my opinion, it becomes something abstract like 'building a raft' and all that nonsense. You can't do exercises at a business school. You can only practice in real life, with real human beings. (CEO).

The Camino offers a situation of extraordinary intensity that can generate and extrapolate real life and thereby actualise a real 'you'. The interpretative repertoire behind this statement is that you show and become the real you not by performing what you normally do but by engaging with circumstances that are highly unusual or downright bizarre (Brown 2012).

This involves a strong focus on 'you' and a development of the 'you' that others can view. The lab heightens reality in the sense that it forces you to find yourself anew on the verge of yourself; and this "comedy of remarriage" (Cavell 1981) with and bordering on vital parts of yourself may lead to a revitalisation and learning. The leadership laboratory is a re-arranged reality to the extent that it borders on hyper-reality, directed at creating an emotionally over-stimulated and hyper-intense kind of living rather than the cleansing calm that characterised the mirror of princes and the classical experimental laboratory. 


\section{Walk the talk}

Within the context of protreptics, human ideas, notions or representations need to pass the test of conversation, questioning and counselling that work as rites of passage and purification. In itself, the human body is not a site of contest, though it is through the strength and virtue of the body of the prince that his soul and character are manifested. In the lab, learning processes and bodily exercise are closely connected. Bodily movements, senses, physical impressions and pains seem to promise more profound and more potent learning processes. This is notable in the mentioned TVdocumentary on the PLLL (and in a long range of more popular books on current pilgrimages as the journey to self-development. Shoes that do not fit and result in blisters and wounds are not only signs of a body in dissolution but of the beginning of a desired mental disordering of familiar identities and thoughts. In our interview with the CEO, the sorely-tried body, hurting legs and blistered feet, is simultaneously emphasised and played down, but no doubt is left about the importance of the physical body. In order to get closer to the unfamiliar part of yourself in need of cultivation, she suggests connecting to the power of real life. In order to become affected, you need 'real life', she claims; and, in that sense, 'real life' becomes (part of) a bio-social technology of power. But, in her formulations, 'real life' is not ordinary everyday practices at the office or something you can learn in classrooms or at business school. Rather, 'real life' can be found and lived in nature furnished with dust, heat, rain and silence. 'Real life' adds bodily movements and sensations in the sense of sweat, hurting blisters and exhausted legs.

There is no doubt that the walking process does something. The first two days are no problem. The following days, while you are walking, you think a bit about the fact that there are three days, and then two days left. But, still, I don't think it kills you. (CEO).

The physical set-up constitutes a living learning apparatus, which makes the participants capable of and become part of complicated connections between reflections, affects and bodies (Despret 2004). 
The PLLL becomes an apparatus through which human bodies are touched and moved by ancient walking routes and the stories inscribed in them. As the documentary portrays this, it is combined with dust, air, burning sun, rain and, particularly, the bodily manifestations of, for example, sunburned skin, painful muscles, hunger, thirst, sweat.

The pilgrim lab is experienced as more real than the ordinary life at the office. It is life, bios, examining and experimenting with human life. It is the experience of the bio-physical life, which is perceived as more present, more real, more provoking of new thoughts and identities. A day at the office with colleagues and their natural office make-up or a wellness retreat at a fancy hotel cannot beat the authenticity experienced on the pilgrimage, the CEO says. The pilgrimage offers a specific topos, which affects, opens and deconstructs the body and thereby examines the human on the verge of itself:

The genuineness and the closeness and the community arising out of a trip like this $[\ldots]$ move something. To me, they move some of the boundaries around values: Why are we here? What is important, and what is absolutely indifferent? [...] That triggers me, and the Camino gives a good framework for internal dialogue and, of course, for external dialogue, too (CEO).

The modulation of the body triggers an inner dialogue. Referring to Massumi (2011), we may say that bodies moving become thoughts that move. The inner dialogue may resemble the self-reflection produced in the mirror of princes but of a different kind. The on-going movement in and of the PLLL signifies how leadership learning is not a matter of developing a finished product, a final character, but about on-going doings and un-doings, on-going processes of learning reaching out into the future and the not-yet-there.

Zooming into the lab, we see participants slowing down, concentrating on doing one thing at a time and not commuting between thousands of phone calls, decisions and expectations. They walk and 
open up their bodies and minds for transformation. They simplify and amplify their presence at one and the same time. The rhythms and vibrations of walking massage new thoughts into their bodies, as well as new identities, new ways of being touched, and new ways of acting. The pilgrimage becomes synonymous with the learning to become affected (Despret 2004). The exhaustion of the body is used as a way of opening up affective zones. They get the opportunity to become empathetic and learn the art of really listening to and tuning in to the atmosphere and thereby feel different, to connect affectively and allow themselves to open up to the unfamiliar. Literally speaking: To walk the talk and move the thoughts

\section{Living travelling companions}

As mentioned at the beginning of the article, young, previously-convicted men with an ethnic and religious minority background are invited as travelling companions. The transformational aspect of 'real life' seems to be further emphasized by casting these living creatures into the PLLL for the purpose of affecting the participants more deeply. As stated above, 'real life' becomes paradoxically more intense than everyday reality at the office because of its simplicity, naturalness and wildness. But in order to become effectively affected, you need not only 'real life' but also 'real beings'.

Animals play a significant role as "real" mind-moving beings in spectacular leadership learning apparatuses - for instance, the rabbit-killer courses from the 1990s and the equine-assisted leadership coaching from the 2000s. Rabbits and horses are important pedagogical tools in the development of a leader's habitus, and they are part of the learning setting exactly because they do not look like or share experiences with the leader. Rabbits and horses are cast as significant animal Otherness.

In the 1990s, a former special force soldier offered leadership courses in which the participants were supposed to take care of and feed rabbits at the beginning of the course and, then, kill and eat 
them afterwards. In these "rabbit killer courses", the objective was to learn the executive good leadership. The passionless execution and detachment from the people you are supposed to lead is not the goal of today's equine-assisted leadership coaching courses. Here the ability to listen to and be engaged in your employee is ideal of leadership. This demands another affective register. Therefore, the courses are concerned with affectively learning the art of managing oneself and others through listening, attuning and cooperating rather than control, discipline and execution. Horses are perceived as particularly sensitive creatures that may reflect sentiments in muscle tone and tension and through a capacity of attunement assist the leader in mirroring him/herself. Rather human advice, as in the mirror of princes, the relation between the human and the animal Otherness moves the mind.

In the PLLL, the productive Otherness is articulated as a radical but also cultural difference that seems to promise something special (for a more profound analysis of this see Hvenegaard-Lassen and Staunæs 2014). As the CEO says,

In my mind, you can't practice these things; then, it will be something, yeah, lost in thoughts, like building a raft and all that nonsense. You can't practice it at a business school. You can only practice in real life, with real human beings (CEO).

In some sense, this resembles ordinary master programmes in management and leadership in which co-students and colleagues play a significant role in self-development and leadership learning. However, the young men at the pilgrimage seem to indicate a promise of a pivotal otherness. The leaders, HR and communication staff, and the former soldier are all signified as White, Danish and Christian, whereas the young men's bodies indicate stories of immigration from the Mideast, Islam and suburban riots. 
Obviously, the young men were cast in the PLLL because of their criminal past and their ethnicreligious-national-racial differences. The documentary as well as newspaper articles and our interview material indicate this intriguing relation by saying "it all began with burning cars". The burning cars and riots were provoked by the Danish cartoon crisis, a controversy around 12 caricatures of the prophet Muhammad, published in the Danish newspaper Jyllandsposten and protested against all over the world by Muslims who felt ridiculed. As a reaction to the perilous situation after the riots in which young minority men burned down schools and cars, the company recruited boys associated with the burned-out cars and schools as "pilgrims" and potential trainees. They were boys who, in the public eye, are ethnic, racial, gendered and religious Others and, by that token, marked as someone relating to this group.

It seems as if the introduction of a cultural-religious-ethnic Otherness "on the edge" of the normal and civilised - perhaps, on the edge of humanity - amplifies the evocation and configuration of the kind of humanity associated with "good leadership. The young men seem to be what Donna Haraway (2008) terms "new creatures of imagined possibilities", promising more than ordinary employees or colleagues. As travelling companions, they may not only fulfil the company's CSR policy but provide the tools needed in the new ideal of leadership learning. Whatever they promise seems troubling and uncontrollable, demanding a particularly sensitive way of executing power. Maybe, they (and all the stories and signs associated with them) do not only demand a Chief Executive but a commander-in-chief, always sensitively registering ahead and ready to move and manage potential breakdowns and threats in the world (Massumi 2009; Hvenegaard-Lassen and Staunæs 2014).

This possible storyline and its military interpretative repertoire are emphasised in the TVdocumentary. The voice-over tells us that the CEO participating in the pilgrimage "has a mission". Accompanying a flock of "ungovernable lads", she sets out "during the worldwide recessions". In 
addition, in the interview with the communication director, we are reminded that the pilgrimage began with burning cars. This indicates the promise of the young men as travelling companions. Being not like you but an ultimate Other, they mirror what you may be capable of leading. To imagine what leading ahead involves demands picturing an ultimate uncontrollable and everchanging Other, which may amplify yourself. What is needed is radical otherness, which may fuel and tune the processes of transformation in both body and mind to evoke the capacities for anticipating and thinking ahead.

\section{A transformative laboratory}

Unlike a classical laboratory, the PLLL is a lived and transformative device designed for change. In the classical socio-psychological laboratory, there is a desire to compartmentalise and retain identities. Usually, the psychological experiments do not bring anything new with them but, rather, repeat what is already known (Stengers 2000). The design is not set up so that the world can articulate itself in new ways or the participants can learn something. That they actually do so is a different issue (Despret 2004). The aim of classical socio-psychological knowledge and experimentation is not the transformation of the participants but, rather, the researcher's understanding and knowledge. The researcher does not participate but observes and experiments in order to learn. In the mirror of princes, it is the participant, i.e., the prince, who must be improved and have his character developed to a higher stage of perfection. In the PLLL, the aims of the classical laboratory and the mirror of princes are synthesised in a desire not only to produce knowledge but also to create new experiences and new understanding or cognition, to attain new competencies but also to change attitude and being. In this lab, everybody - both leaders and young men - must learn something but not necessarily the same thing or in the same way. There is diversity here; and this diversity seeks distinctions. The Others (the boys), are not merely passive materials. In order not only to provide promises but to live up to them, they must be in a process of 
development. It is rather a case of their learning becoming the precondition for the leader to increase his or her capacity and move towards what he or she can become, while never actually attaining it. The TV-documentary, therefore, focuses on the process which the young men undergo and the movement that they must take place in order to develop from "delinquent immigrant" to trainee in the company, which is not only an effort in diversity or integration that concerns the "meeting of cultures and common understanding". The TV-documentary, therefore, also describes the requirements that must be in place to establish a dynamic learning context from which the leader can also learn.

That the ethnic, racial, national or religious Others learn and develop is, thus, not merely a question of decency or ethics. It is also a necessary element in self-leadership insofar as it is necessary to cultivate self-leadership in order to cultivate the possibility of self-transformation. Let us take a closer look at the direction and object of the self-transformation process.

\section{Virtuality as object of transformation and the direction set}

In the mirror of princes, the direction of self-transformation is obvious. The overall goal of counsel for princes was to develop the prince's general humanity. Recognizing the existence of a common direction for the good person and good society was still fundamentally important for princely character formation. This is why counsel from other spheres of knowledge or morally-privileged people had such a decisive role and was a special technique, whether this concerned important individual cases or the more general mentoring of overall humanity and moral ability involved in the mirror of princes. It was of absolute importance that the king was able to attain Bildung and step into character.

In the PLLL, the idea of an overall final goal setting the right direction for the entire journey is not the essential element. Instead, a crucial concern is establishing a preparedness: a getting-ready to receive a dislocating jolt and an impetus from that Other, which is itself in transformation. This is 
an impetus that is, by definition, predictable to some extent and is specifically arranged to be so. The concern is becoming and learning to become affectable, so that one can be influenced by others who push in directions that are unpredictable and initiate quantum leaps to cover distances it would not have been possible to cover in isolation.

For the leader, the issue is not so much to discover his or her true character. Rather, it is about increasing a relational competence, so that it becomes possible to be affected and affect others in unexpected directions. The LLL is designed for those who lead to lose control in controlled circumstances, so that they are transformed and empowered in ways they are not in full control of. One enters upon a journey with the self as the person one could become but never actually becomes. Here, the leader's virtual self appears as an important stake. The virtual self involves that affectivity attains a certain position in the PLLL and that one approaches emotions in a particular way.

\section{Determinate and indeterminate affectivity}

In the protreptic setup, affectivity and emotions appeared as variables that affect and challenge the leader. This was not a challenge that forced or allowed new cognition, however. Rather, the prince was able to claim his humanity in relation to such affectivity by being able to dominate and control his emotions. The decisive thing with regard to emotions and passions was to suppress or, at least, harness them (Hirschman 1997). Not until the leader was able to avoid being taken over by emotion did he become the ideal to be followed. He had to take control over his emotions to show the right way. This made him worthy of dominion over other people. It was exceedingly important for the prince to step into character but also to retain that character and self through and in spite of emotional challenges. The mirror of princes, therefore, was designed to develop certain emotions and various passions but always so that they appeared as a lower category than rational cognition and moral correctness, which must be retained in spite of the existing emotions. Emotions were there to be accounted for and controlled. 
In a similar manner, the rabbit-killer courses of the 1990s were designed to generate emotions in leaders but only for the leaders to feel emotions without losing control. By retaining control and power over the self, the leader is able to retain power over others and control them.

In contrast to the moderation of emotion, the PLLL heightens the tension of affectivity. Here, one focuses on and mobilises moods and affective states that can have an impact on and prompt the leader to such a degree that he or she momentarily loses control and is forced to develop. We have already touched on how the participants are affected through vibrations, rhythms and movement that continuously activate the senses and intuition. However, the PLLL is also designed to affect the leaders by more than vague affective states of mind. This is because the laboratory is also interested in provoking certain affective states. This is why Ernest Bloch's (1959) "anticipatory affects (Erwartungsaffekte)" assumes a predominant role in the lab, as described by the CEO. In addition to the affects, which are coupled with self-reflection, attitudes of expectation, anticipation, and reorientation appear everywhere in the material.

The CEO was affected by the PLLL even as she prepared for the pilgrimage:

I suppose I could sense that I was going on a trip that would be quite challenging in physical as well as mental terms, all the while I was looking forward to meeting the lads. I had not met them before and had been in anticipation of it for a long while, which is why I was very caught up in how exciting it was going to be. I can now look back on it as a kind of expectation and anticipation while I was packing but also humility towards the task, because it was to be mentally and physically demanding. This was why I tried to charge myself in advance, if you can even say that. (CEO)

She longs to get going but also experiences nervousness or perhaps fear of what may come, as she doubts whether she will be able to overcome the challenges she does not yet know and can only 
partially imagine. She is enveloped in emotional labour even during the preparatory phase. She not only allows herself to feel what she is doing but works actively with her anticipatory affectivity. In this manner, it becomes possible for her to reduce passive and negative anticipatory affects such as fear and doubt. Instead, she decides to replace them with other more positive moods such as hope and trust in which one emotionally anticipates good things from the new and upcoming: useful gifts that enliven and grant a surplus and, thus, open the possibility for a better life that she does not yet know (Raffnsøe 2013). She knows that this attitude is both necessary and anticipated in the lab in order for it to work.

The importance of anticipatory affectivity with regard to the CEO's preparations suggests that what is in a process of becoming in the PLLL is of extreme importance. Thus, those who participate do not so much take their bearings in what has actually happened or is happening. Instead, they focus on what may happen and what may occur through what is happening (Ryle 1949). In the PLLL, one leaves behind the actual and the given (Plato and Heidegger 1947; Heidegger 1979) and focuses on another very real aspect of the world and being, namely, the virtual (Deleuze 1988; Deleuze 1996). In this way, one stresses the force that is operative in the existing and makes itself felt through it by putting it into motion, so that it transcends itself and develops in various directions (Massumi 2002; Raffnsøe 2013). As is evident in the quote above, the leader seeks to prepare or even dispose herself toward this sort of dynamic and productive rupture so that it may apply and break up what exists and indicate new directions.

The CEO has already sensed and anticipated this while she prepared for departure. Indeed, she continuously works with this issue while she moves around in and with the PLLL. In order to initiate and encourage on-going virtual movement, which she is not able to maintain on her own, it becomes of decisive importance to establish a relation to others and become affective in relation to them, even as she is attentive to how they affect her "Befindlichkeit" (Heidegger 1979) or her way 
of being in a mood as a way of being or finding herself in the world. However, it is also exceedingly important for the leader to attune her own situatedness, so that her affectivity is directed positively towards and opens up to that which approaches through all these relations and ways of being in the world. In these ways, the PLLL breaks with character formation and selfcontainment as the final desired goal of the mirror of princes. Rather what must be developed is the capacity of governing not life as such but rather the potentiality of life (Staunæs 2011). What must be cultivated is life's and the leader's ability to stay ahead of time.

\section{Conjuring forth and distributing what is human}

Thus, the PLLL aims at bringing forth, examining, and developing a certain modality of being in the leader. This human modality or format of humanity distinguishes itself from the mirror of princes. As hinted at earlier, the mirror of princes directed and committed itself to developing the prince's or the leader's universal humanity. By doing so, a general and collective direction of cognition and self-transformation was indicated among those who took part in this particular device. This universal humanity simultaneously constituted an end or goal that allowed the prince who attained it to transcend the given context in which he had come about. By entering into this counselling device, the prince was able to generate conceptions of elevating himself to a standard at which he could hold a mirror to himself and catch a glimpse of his own humanity. In this spectacularly human auto-affection, the on-going reflection could be brought to termination, so that the leader was able to grasp the world from a privileged and human vantage point.

The generation, revitalisation, and intensification of the human, which takes place in contemporary LLLs, differ from a search for an identification with the universally human as it is found in the mirror of princes and which still seems to be at play in the classical socio-psychological experiments (Staunæs et al. 2014 ). The LLL is not a mirror but a diffraction machine that refracts what precedes it and instigates an on-going reflection and development. 
The LLL, therefore, does not involve an ordinary cultivation of the human character in general. Instead, the device opens up a space for a situated and particular kind of humanity. This is exactly the kind of humanity that originates and may intervene in a given context. In turn, the development of a given context, therefore, comes to depend upon this human intervention. The leader is very much a person who steps forth as responsive to the leadership context within which her leadership applies. At the same time, it is a kind of humanity that unfolds anew in a situated and limited form, yet continuously and without termination (Raffnsøe 2010). In the LLL, the individual's humanity is very much coupled with what this person is in the process of doing or becoming.

In this lab, the leader no longer appears as a person who finally locates him- or herself but becomes a person under constant development and becoming, as he or she moves ahead of him- or herself in time. This is not a leader who is constantly on a route back to the self, as was the case in the mirror of princes. The leader becomes a person who is on an on-going journey, not towards but with himor herself.

\section{Leadership as pilgrimage}

The setup and the denomination of the PLLL provide this in an emblematic and condensed form. On the journey, the leader appears as a human being who, after leaving behind domestic comforts and a familiar landscape, becomes a peregrine (Latin peregrinus), an outlander and a foreigner, passing through (per-) the fields or the territory (-ager) (cf. Onions et al. 1966). What becomes evident to the wayfarer on his or her journey towards a distant, sacred place is the experience that "the going is more memorable than the getting there." For the pilgrim leading her/himself and others, what counts is what happens along the road. It is not primarily a mystical goal; neither is it in itself the relationship actually established to those in his/her care. Instead, what is crucial is the reawakening, the re-invigoration and the resurrection of human existence and its ability to relate 
actively to others and to oneself in such a way that it is able to move ahead of itself and make the world reappear in a new light.

As a consequence, the most important canonical precursors for the PLLL and its conception of leadership are not to be found in Biblical stories of exile and exodus but, rather, in tales of conversion. The decisive trait of this peculiar lab is not so much that the participants leave the world as they know it behind and enter a peculiar interim state in which they remain focused on a common goal or destiny. What is essential is not the movement towards and the attainment of a promised land but the experience of a heart aroused that permits one to reach into and anticipate the future.

In the travelling laboratory an old, almost forgotten connection between travel, work (French travail), and effort is (re)discovered and expressed. Travelling is hard work, also for the self (Espedal 2006), but it also becomes clear that work (French travail) is a difficult journey (English travel) along an open road, a kind of suffering and penance - perhaps, even torment - through which humans can be transformed and, thus, attain a new form of humanity, as is also evident in the title of David Whyte's best-selling Crossing the Unknown Sea: Work as a Pilgrimage of Identity (Whyte 2001). It is a precondition for leadership that the leader is a person who is on an on-going and non-terminating journey. It is a kind of humanity that is constituted in the given space and which responds to the given while it stretches ahead of itself, towards that which is not yet known.

The goal is, thus, for the leader and for leadership, through various and facilitating learning processes, to reflect upon and develop the self with regard to entering into and leading human relations to the self and others in a situated and flexible manner. This specific form of humanity comes about through and as a result of the laboratory. This effect is configured as a reflective and affective humanity that is always on the margins of itself. Polemically speaking, the human must 
experience the human with the aim of developing and strengthening it - in between and through others.

\section{A new kind of leadership}

Currently, "creating a capacity for continuous renewal" in an inconstant environment is highlighted as a necessity for any company that seeks to shape its own future and does not declare itself satisfied with catching up (Hamel and Prahalad 1996). In the LLL, a new art of governing is investigated and developed that may be viewed as an attempt to keep up with these challenges and stay ahead of time. In character, this kind of leadership differs from leadership in the traditional sense. In the Western societies, leadership has since classical Antiquity been conceived as closely related to the notion of the ruler as a leader being in control and command (Raffnsøe 2013). The traditional leader is supposed to be a helmsman in control, able to take the lead and set the overall direction by virtue of the fact that he possesses an insight in the goals we should all try to move towards. As developed in the PLLL, leadership is conceived as emerging in response to and acting on a given situation and its virtuality..

This kind of leadership distinguishes itself from the influential art of governing that has been presented, articulated and justified in the form of a study of, an express attention to and a development of a specific logic inherent in the governance of men. This art of governing was first suggested as rationality in its own right in Plato's Statesman and the Old Testament - later to be designated and articulated as a specific human activity in Christian pastoralism, modern reason of state and cameralism (Raffnsøe 2002). As studied and described by Foucault (2008, 2009, 2010, 2011), governing in the form of governance can be understood in terms of the way a shepherd tends his flock. Governance focuses on a protective care for and development of the welfare of both the flock and its individual members. With governance and its inherent rationality, a form of governing is implemented that continually revives, replenishes and reconstitutes the community, which does 
not subsist beyond its leadership. This form of governmentality remains very present in the leadership lab, as the pilgrim leader stays very focused on both rounding up the moveable flock and taking care of the various individual members. Still, a new decisive element is added here as governance enters into and becomes part of a learning process in which it is essential to develop an attitude that permits the leader to stay ahead of the flock of which she is in charge as well as take proper care of the flock. The ability to be affected in the right way by ungovernable others so that one is able to maintain an anticipatory affectivity becomes a preoccupation that forms an essential prerequisite for proper governance. As virtuality and a future-oriented attitude enter into the game of governance and begin to form conditions of possibility for proper governmentality, they change the basic rules of the game in ways that are not likely to appear in a traditional analysis of governmentality.

Within the PLL, a new habitus and relational capacity are studied and developed in the leader: an aptitude to respond to the dispositional dynamics of the multitude of which she or he is accountable in a way that permits her or him persistently to go outside and move ahead. In this way, the leader may become capable of going beyond or transgressing a privileged attention to the guardianship of the group or the goals already set, as she or he includes both objectives in a new context of her or his own making.

The lab is granted a core position, as it sets up an experimental, living, affective device, able to touch and challenge given human capacities in order to permit a new kind of leadership. The device allows the leader, through various facilitating processes, to feel and develop in order to enter into and manage human relations. The lab also makes it clear how a higher capacity for learning and affectivity has become the ideal for leaders in our time. Leadership now concerns a capacity, not only to establish human relations and to allow oneself to be touched and changed, but to establish human relations that change and touch others that partake. Laboratories offer an experimental and 
living apparatus that, through manipulations at a certain level of intensity, may facilitate human experiments with and experience of the self in its relation to other people and their humanity.

\section{Conclusion}

Such leadership is precisely not an expression of pure innate humanity. It is responsive and must also be specific in terms of temporality and domain. This also involves a kind of humanity that is not neutral or unselfish, although it may often appear to be at first. It is simultaneously a leadership humanity that must constantly be asserted and unfolded over and against other kinds of humanity. Even if it appears to be in place before the ethnic, national, religious Others, it also asserts itself through and in regard to exactly them. The young ethnic, national, religious men are invited into the organisation and are given a trainee position at the bottom rungs of the organisation, that is, if they can deal with the journey, even as they act as fuel for the developmental process of the leaders, which, in turn, makes it possible for the leaders to continue leading - even when the members of the organisation move and change. This is leadership humanism in motion, which does not annul the boundary to and include others in its development. Rather, the differentiation from and minorisation of the Others are retained as an essential part of human development. It remains essential to stay ahead of others in order to stay ahead of time.

What is at play in this sort of experiential lab is the potential for generating, revitalising, and intensifying a particular competence in human relations. This includes a capacity to be sensitive and balanced and to initiate one's own character development. When managers take the learning of learning to the next level, a virtual space is opened. This involves a capacity, rather than a qualification and a competency as such. The capacity for leadership that is to come out of the experiment is, as we have shown, a disposition towards what will happen and occur rather than towards what has already taken place. Furthermore, a certain emotional preparedness is trained, which involves the affectivity of expectation, anticipation and (self-)reflection. Developing 
leadership to contribute to organisational evolution is no longer merely a question of exploiting a given amount of time as efficiently as possible, of shaping or completing personalities or great characters, or even of reviewing and redefining oneself critically. Instead, it is about amplifying the ontology of capacity in management to become receptive to what the self, the organisation and even its 'outside' (Prahalad and Ramaswamy 2004; Lopdrup-Hjorth 2013) may virtually become rather than what one already knows about oneself (Staunæs and Juelskjær 2014). This involves a positive attitude towards the future. It is all-important to be in a state of readiness, such that one is positively oriented towards future events and on par with and ready to respond to the as-yet unknown. The arrival of the LLL indicates that it has become of crucial importance to stay ahead of time by building up a firm attitude towards the new that enables one to respond more than just adequately to the advent of a new time. This attitude involves an ongoing auto-critiqual stance, that does not assume the shape of a severe criticism and rejection of the present, the form of an anticipatory transgression of any present.

Still, the question remains whether the subsequent processes - in particular, processes of minorisation - may later obstruct organisational productivity and capacity, talent management and development, when the participants in the LLL return to work in the organisation. This may be the subject of future research.

\section{References}

Aristotle. 1964. Protrepticus: A Reconstruction. [Notre Dame, Ind.: University of Notre Dame Press.

Barad, Karen Michelle. 2007. Meeting the Universe Halfway: Quantum Physics and the Entanglement of Matter and Meaning. Durham: Duke University Press.

Blackmore, Jill. 2011. "Lost in translation? Emotional intelligence, affective economies, leadership and organizational change". Journal of Educational Administration and History 43 (3): 207-25.

Bloch, Ernst. 1959. Das Prinzip Hoffnung. Frankfurt am Main: Suhrkamp. 
Brown, Steve. 2012. "Experiment: The experiment in living". In Inventive Methods: The Happening of the Social, eds. Cecilia Lury, Nina Wakeford. London: Routledge.

Cavell, Stanley. 1981. Pursuits of Happiness: The Hollywood Comedy of Remarriage. Cambridge, Mass.: Harvard University Press.

Czarniawska-Joerges, Barbara, and Höpfl, Heather. 2002. Casting the Other: The Production and Maintenance of Inequalities in Work Organizations. London, New York: Routledge.

Deleuze, Gilles. 1996. "L'actuel et le virtuel". In Dialogues, eds. Gilles Deleuze, Claire Parnet. Flammarion: Paris: 177-185.

Deleuze, Gilles. 1988. Bergsonism. New York: Zone Books.

Deleuze, Gilles, and Félix Guattari. 1991. Qu'est-ce que la philosophie? Paris: Editions de Minuit.

Despret, Vinciane. 2004. "The body we care for: Figures of anthropo-zoo-genesis". Body \& Society 10 (2): 111-34.

Drucker, P. F. 1992. The Age of Discontinuity: Guidelines to Our Changing Society. New York: Harper and Row.

Drucker, Peter F. 2007. Innovation and Entrepreneurship. Oxford: Butterworth-Heinemann.

Drucker, Peter F. 2008. The Age of Discontinuity: Guidelines to Our Changing Society. New Brunswick, London: Transaction Publ.

Drucker, Peter Ferdinand. 1993. Post-Capitalist Society. New York, NY: HarperBusiness.

Elkjaer, Bente, and Russ Vince. 2009. "'Good night and good luck'". Management Learning 40 (5): 609-10.

Espedal, Tomas. 2006. Gå, eller, kunsten å leve et vilt og poetisk liv. Oslo: Gyldendal Norsk Forlag.

Florida, Richard L. 2002. The Rise of the Creative Class: And How It's Transforming Work, Leisure, Community and Everyday Life. New York, NY: Basic Books.

Fullan, Michael. 2001. Leading in a Culture of Change. San Francisco: Jossey-Bass.

Foucault, Michel. 1980. Knowledge/Power. New York: Pantheon Books.

Foucault, Michel. 2008. The Birth of Biopolitics. New York: Palgrave Macmillan.

Foucault, Michel. 2009. Security, Territory, Population. New York: Palgrave Macmillan.

Foucault, Michel. 2010. The Government of Self and Others. New York: Palgrave Macmillan.

Foucault, Michel. 2011. The Courage of Truth. New York: Palgrave Macmillan. 
Gitlitz, David M. and Davidson, Linda K. 2000: The Pilgrimage Road to Santiago. New York: St. Martin's Press

Goleman, Daniel. 1996. Emotional Intelligence. London: Bloomsbury.

Gray, Vivienne. 2011. Xenophon's Mirror of Princes: Reading the Reflections. Oxford, New York: Oxford University Press.

Hamel, Gary. 2007. The Future of Management. Boston, Mass.: Harvard Business School Press.

Hamel, Gary, and C. K. Prahalad. 1996. Competing for the Future. Boston, Mass.: Harvard Business School Press.

Haraway, Donna Jeanne, Grossberg, Lawrence, Nelson, Cary, Treichler, Paula A. 1992. The Promises of Monsters: A Regenerative Politics for Inappropriateld Others.

Haraway, Donna Jeanne. 2008. When Species Meet. Minneapolis: University of Minnesota Press.

Harvard Business Review's 10 Must-Reads on Change. 2011. HBR's 10 Must-Reads: On Change. Boston, Mass.: Harvard Business Review.

Heidegger, Martin. 1947. Platos Lehre von der Wahrheit: Mit einem Brief über den "Humanismus". Bern: Francke.

Heidegger, Martin. 1979. Sein und Zeit. Tübingen: Niemeyer.

Howe, David. 2008. The Emotionally Intelligent Social Worker. Basingstoke [England], New York: Palgrave Macmillan.

Hvenegaard-Lassen, Kirsten, and Dorthe Staunæs. 2014 (Forthcoming). "Walking whiteness. Tools for a frictional analysis." . In Gender, Work \& Organisation

Latour, Bruno. 1988. The Pasteurization of France. Cambridge, Mass.: Harvard University Press.

Latour, Bruno, and Steve Woolgar. 1986. Laboratory Life: The Construction of Scientific Facts. Princeton, N.J.: Princeton University Press.

Livingstone, David N. 2003. Putting Science in its Place: Geographies of Scientific Knowledge. Chicago: University of Chicago Press.

Lopdrup-Hjorth, Thomas. 2013. "Let's Go Outside": The Value of Co-creation. Ph.D. thesis, Doctoral School of Organisation and Management Studies, Copenhagen Business School.

Management \& Organizational History. 2013. Special issue: Doing historical research in management and organizational studies. Management \& Organizational History 8, (2).

Massumi, Brian. 2009. "National enterprise emergency". Theory, Culture and Society 26 (6): 15385. 
Massumi, Brian. 2002. Parables for the Virtual: Movement, Affect, Sensation. Durham, NC: Duke University Press.

Michael, Mike. 1996. Constructing Identities: The Social, the Nonhuman and Change. London: Sage.

Nelson, R., and S. Winter. 1982. An Evolutionary Theory of Economic Change. Cambridge, Mass.: Belknap Press of Harvard University Press.

Plato. 2008. The Seventh Letter. In The University of Adelaide Library.

Prahalad, C. K., and Gary Hamel. 1990. The Core Competence of Corporation. Canada: Harvard Business School Reprint.

Prahalad, Coimbatore Krishnarao, and Venkatram Ramaswamy. 2004. The Future of Competition: Co-creating Unique Value with Customers. Boston, Mass.: Harvard Business School Pub.

Raffnsøe, Sverre. 2002abc. Sameksistens uden common sense. Vol I-III. Copenhagen: Akademisk Forlag.

Raffnsøe, Sverre 2010. "The Obligation of Self-management: The Social Bonds of freedom". In Villum Foundation and Velux Foundation. The Annual Report 2009 : 56-63.

Raffnsøe, Sverre: "Beyond Rule. Trust and Power as Capacities. Journal of Political Power 6 (2): 241-260.

Raffnsøe, Sverre, Marius Gudmand-Høyer, and Morten S. Thaning. 2014 (forthcoming). Foucault. A Research Companion. London: Palgrave.

Ratner, Helene. 2012. Promises of Reflexivity: Managing and Researching Inclusive Schools. Copenhagen: PhD School of Economics and Management.

Ryle, Gilbert. 1949. The Concept of Mind. London, New York: Hutchinson's University Library.

Schön, Donald A. 1983. The Reflective Practitioner: How Professionals Think in Action. New York: Basic Books.

Schumpeter, Joseph A. 1947. Capitalism, Socialism, and Democracy. New York, London: Harper $\&$ Brothers.

Seneca, Lucius Annaeus, Basore, John W. 1979. Moral Essays. Cambridge, Mass., London: Harvard University Press.

Senge, Peter M. 1990. The Fifth Discipline: The Art and Practice of the Learning Organization. New York: Doubleday/Currency.

Sinclair, Amanda. 1998. Doing Leadership Differently: Gender, Power, and Sexuality in a Changing Business Culture. Victoria, Australia: Melbourne University Press. 
Sinclair, Amanda, and Valerie Wilson. 2002. New Faces of Leadership. Carlton South, Vic.: Melbourne University Press.

Staunæs, Dorthe, and Malou Juelskjær. Post-psykologisk subjektiveringsteori. problemet med personlighed version 2.0). In Personlighedspsykologi, eds. J. Danmeyer, Simo Køppe. Hans Reitzels Forlag: Copenhagen.

Staunæs, Dorthe, Malou Juelskjær, and Hanne Knudsen. 2009. "Psy-ledelse. nye former for skoleledelse ses igennem tre optikker". Psyke \& $\operatorname{Logos}(2)$.

Staunæs, Dorthe. 2011. "Governing the potentials of life itself? interrogating the promises in affective educational leadership". Journal of Educational Administration and History 43 (3): 227-47.

Staunæs, Dorthe, Dupret, Katia, Adriansen, Hanne, Nickelsen, Niels Christian and Steen Høyrup Pedersen. 2014. (eds). Læringslaboratorier og -eksperimenter. Aarhus: Aarhus Universitetsforlag.

Stengers, Isabelle. 2000. The Invention of Modern Science. Minneapolis: University of Minnesota Press.

Thomas d'Aquin, J. G. Dawson, and Alessandro Passerin D'Entrèves. 1948. Aquinas: Selected Political Writings. Edited with an introduction by A. P. d'entrèves, translated by J. G. Dawson. Oxford: B. Blackwell.

Thompson, Sue, and Thompson, Neil. 2008. The Critically Reflective Practitioner. New York: Palgrave Macmillan.

Whyte, David. 2001. Crossing the Unknown Sea: Work as a Pilgrimage of Identity. New York: Riverhead Books.

Xenophon. 1960. Cyropaedia 1. 1. London, Cambridge, Mass.: W. Heinemann; Harvard University Press. Press. 